UDC: $378.018 .43: 378.22: 78$

DOI: https://doi.org/10.24195/2414-4665-2017-6-16

\author{
Liudmyla Havrilova, \\ Doctor of Pedagogy, professor, \\ Head of the Department of Theory and Practice of Primary Education,
}

Nadiia Voronova,

PhD, associate professor, Department of Culture Studies, Aesthetics and History, Donbas State Pedagogical University, 19, Hen. Batiuka Str., Sloviansk, Ukraine

\title{
ONLINE TRAINING COURSE FOR TEACHING MASTER-DEGREE MUSIC STUDENTS
}

The paper deals with the relevant issue of modern university education - implementing online training techniques in the process of teaching Master-degree students majoring in Music. There have been suggested an authors' course of online training, namely occupation-related theoretical course of Music history "History of Music Art in Ukraine and a special course "Multimedia Teaching Techniques in Art education". In order to check the efficiency of the technologies implemented into the educational process there has been conducted the final testing in terms of "History of Music Art in Ukraine" course in the experimental (who were taught using the above mentioned online course) and control groups (who were taught using traditional methods) of Master-degree students. Purposefully designed testing in History of Music covered different aspects of the students' professional competence: its cognitive component (key and specific knowledge of the history of domestic music art development, specific laws of art, understanding music genres, etc.), maturity of analytical and listening skills (the ability to recognize a music work by the tone, determine its genre, etc.), maturity of axiological skills. It should be noted that some tasks were designed in the form of a music quiz to check the music perception skills and knowledge of Ukrainian music works by ear. The assessment was performed using 100 point scale according to the requirements set. The carried out examination of the respondents' professional competence has proved the efficiency of using e-learning in terms of the online course "History of Music Art in Ukraine".

Keywords: online training, online course, history of music art in Ukraine, multimedia technologies in art education, Master-degree students majoring in music.

\section{Introduction}

In recent decades, information and communication technologies have been getting more and more widely used in the educational process of most European countries, the US, as well as Ukraine. Today, there have been created regulations and guidelines for implementing ICT into the educational process, analyzed and experimentally checked new teaching methods based on computer and internet technologies: e-learning, open education, blended learning, etc. In order to provide new forms of teaching there have been developed various e-resources (such as etextbooks, program tools, etc.). Online training course is one of the major forms among the great variety of techniques.

Theoretical and applied aspects of online training are actively elaborated in domestic and international scientists' works (V. Bykov, N. Zhevakina, V. Kukharenko, V. Oliinyk, O. Spirin, A. Yatsishyn; V. Soldatkin, A. Khutorskoy, C. Wedemeyer, R. Dellinh, B. Kholmberh, O. Peterson, A. Rossett, R. Schank and others).

The theoretical background of online training is considered in the philosophy of constructivism. Many scientists distinguish the interaction and communication as a basis for the theory and practice of online training $[3 ; 4$; 5].
Among a number of domestic scientists' interpretation, we believe that the most accurate variant is the one suggested by V. Bykov and V. Kukharenko [2] who consider online training as a form of organization and realization of the educational process when the participant performs the educational interaction essentially and in an extraterritorial way. Depending on the character of organizing the participants' educational interaction and the way of communication channel construction there are traditional (extramural) and electronic (online) forms of study [2, p. 9].

Sharing V. Kukharenko's opinion, we believe that the main form of e-learning implementation is online course as a designed process by a teacher aimed at acquisition of the structured information, as a reproduction of the traditional educational process by means of ICT (communication, collaboration, self-study, etc.) [1, p. 53].

The study of the history and experience of the development and implementation of online courses into the educational process shows that they have recently started to cover music education. There are some online courses in theory and methods of music education, but the purposeful use of e-learning in the field of music education has just started its development.

The paper aims to present and analyze our experience of projecting and designing online courses for the 
system of Master-degree students' training in the field of music education, namely the course "History of Music Art in Ukraine" and "Multimedia Technologies in Art Education". They have been created in order to provide a high level of future Music teachers' training. Besides, the paper also aims to consider the specificity of the development and application of online courses for both traditional and new disciplines in the curriculum of Masterdegree students majoring in Music Art.

\section{Discussion}

Master-degree Music students study a number of disciplines related to the field of the history of music. One of such subjects is called "History of Music Art in Ukraine" which covers the peculiarities of the development of Ukrainian music culture starting from the ancient times until today. The online course in this subject was created according to the well-known model ADDIE for eenvironment developed by M. Simonson, S. Smaldino and M. Albright. It involves the following stages: analysis (of the content, education environment, determination of the subject and the peculiarities of the software), designing (determination of the expected results, teaching and assessment methods, etc.), development (preparing materials, exercises, tasks, topics, etc., as well as planning the course organization), implementation (conducting the course, organizing the interaction between the educational process participants), assessment (checking if the goals have been achieved, if there is a necessity of correcting the content of training or teaching methods) [4].

In general, the online course "History of Music Art in Ukraine" included in the curriculum of future Music teachers' training, demonstrates the fulfillment of the blended learning principles, which according to $\mathrm{V}$. $\mathrm{Ku}$ kharenko, combines the flexibility and expediency of the online course and the advantages of traditional methods [1].

Another online course "Multimedia Technologies in Art education" elaborated for Master-degree students majoring in Music is focused on the profound acquisition of computer technologies in the field of art education, Mastering of multimedia technologies and e-resources. It provides students with necessary scientific and methodical information for the systematization and expanding of knowledge of methods of teaching art disciplines using ICT, contributes to the formation of ICT skills for conducting lessons at school, as well as for the creation of their own electronic teaching resources.

The online courses "History of Music Art in Ukraine" and "Multimedia Technologies in Art education" consist of the introduction, practical and assessment stages.

The introduction part on each course is aimed at providing students with necessary information for their efficient work in the e-environment. It involves the following components:
- course syllabus with the determined plan, structure, assessment forms and criteria, information about printed and other resources, available software, etc.;

- glossary including keywords and terms;

- author's e-training assets (for example, multimedia textbook "Ukrainian Sacred Music", e-versions of study guides, etc.).

The introduction part of every online course involves text lecture materials, multimedia presentations, schemas, tables, as well as multimedia content (fig. 1). It is worth noting that theoretical material is presented concisely. Future Music teachers also obtain supplementary resources (combined in database folders about composers' biographies, operatic works, music materials in the course "History of Music Art in Ukraine"; textbooks in the educational field "Art" for schools, lessons compendia, methodical recommendations on multimedia technologies use at lessons, lists of recommended reading and internet resources, etc.), the access to music works for listening to (according to the study program), multimedia tools in different kinds of art (reference e-books "Masterpieces of Classical Music", "Art Treasures", "Theatre Encyclopedia", "Cinema Encyclopedia", "Musical Instruments", "Treasures of Ukrainian Culture", etc.), collected in Google Drive.

Practical part of every online course has its specificity. For instance, the practical part of the course "History of Music Art in Ukraine" aims to form listening, analytical, and creative skills in students. Special tasks for individual work requiring using Internet recourses, selection of multimedia content, their processing in special programs and arrangement in the form of multimedia presentations, tables, etc. are elaborated in its framework. Students collect all the fulfilled tasks in e-portfolios. Here are some examples of the tasks:

students have to distinguish certain stages of the Ukrainian music development (different directions), build a composer's creative profile, determine main stages of his/her creative career and their significance for the formation of author's artistic and aesthetic principles, note the most significant periods of his/her creative development; arrange a project in the form of multimedia presentation or interactive poster using textbooks on the history of the Ukrainian music (the list of recommended books is provided) and e-resources.

students have to present one of the Ukrainian composers' works according to their own scenarios (they are provided with a list of recommended works) using the multimedia content (audio and video fragments, illustrations, pictures, fragments of films, etc.) and keeping to the integrity of the subject matter. The projects are to be arranged in the form of a presentation, interactive poster, or a video (AVI). 


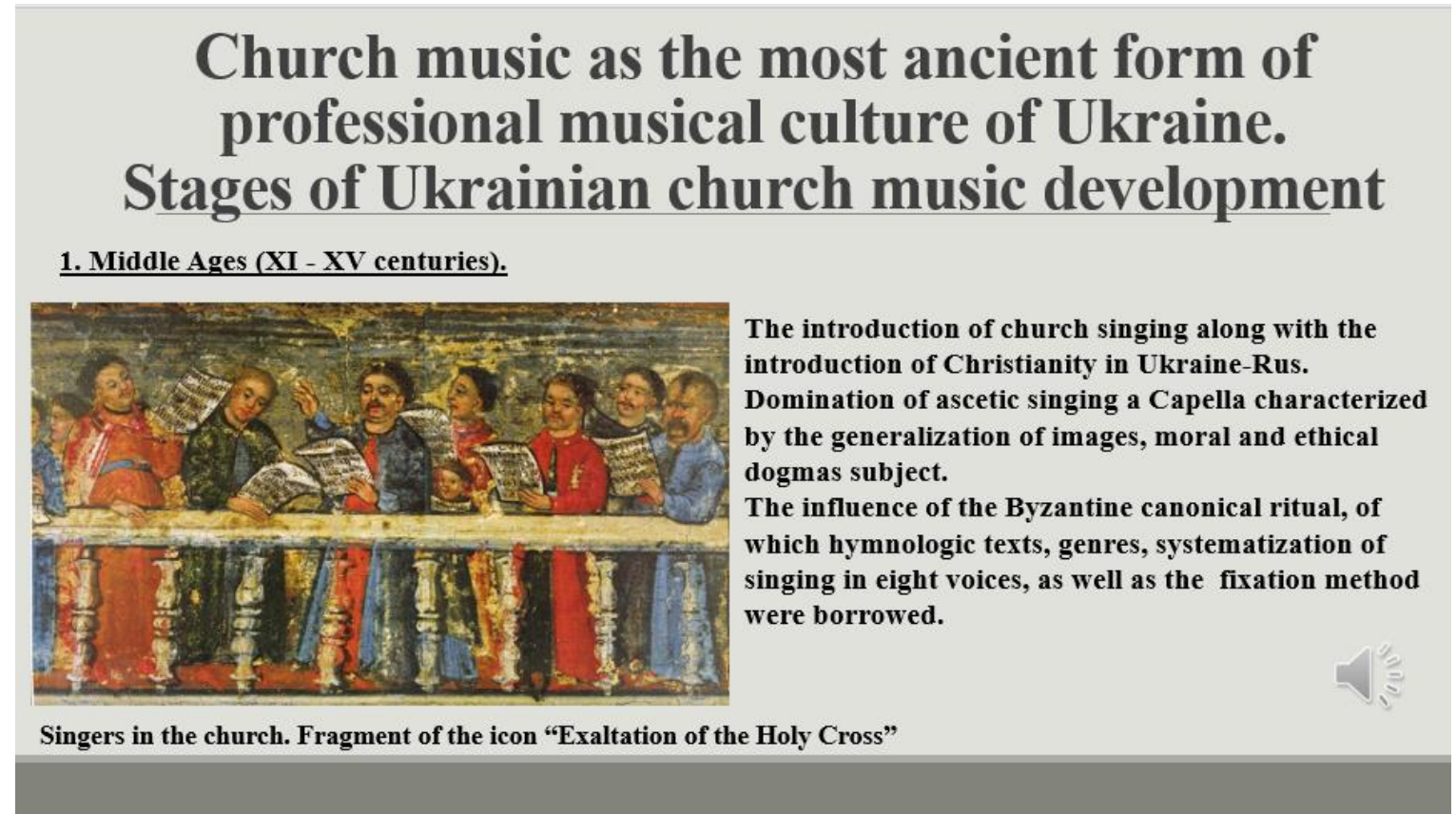

Fig. 1. Illustrations in the presentation in the framework

of the online course "History of Music Art in Ukraine"

The assessment of knowledge in the field of music history, as well as listening skills gained in the process of studying the course "History of Music Art in Ukraine" is carried out by means of testing (MOODLE helps to evaluate students' knowledge and skills effectively by means of the "Test" module) with the instant obtaining of the results.

In the practical part of "Multimedia Technologies in Art Education" course special attention is paid to the formation of multimedia application skills at the lessons, thus, the tasks for self-study involve Mastering the programs for processing audio and video fragments (Nero Wave Editor, Nero Vision), graphic editors (Paint, GIMP, Photo Pos Pro), Windows Movie Maker, preparing multimedia content for Music and Drawing lessons, integrated course "Art", making tests with multimedia content in MS PowerPoint, MyTest X та Hot Potatoes (fig. 3), designing interactive posters, maps, videos by using scribing, etc.

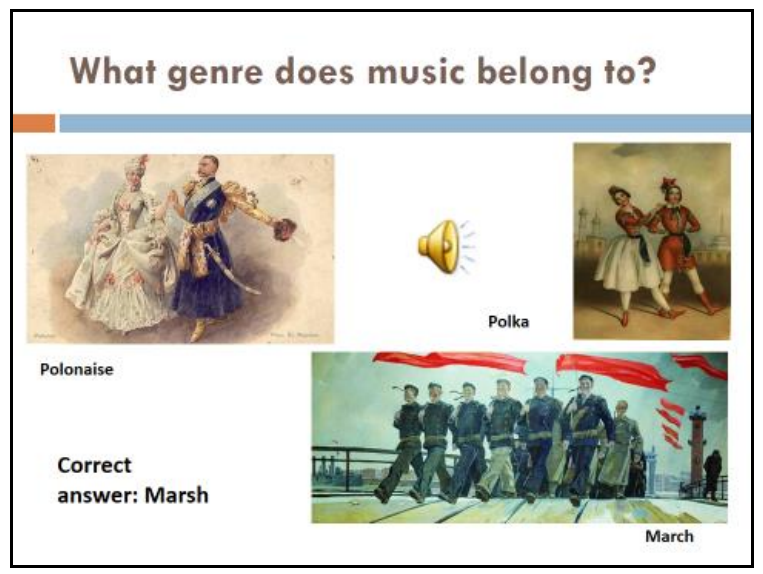

Fig. 3. Testing with multimedia content (MyTest X and PowerPoint)

in the framework of "Multimedia Technologies in Art Education" course

The use of the online courses described for teaching Master-degree students majoring in Music contributes to their all-round development, namely, cognitive, activity and reflexive aspects of their professional competence, as well as to the increase of their occupation-related skills.

Research Methods and Results

Science and Education, 2017, Issue 6
In order to check the efficiency of the technologies implemented into the educational process there has been conducted the final testing in terms of "History of Music Art in Ukraine" course in the experimental (who were taught using the above mentioned online course) and control groups (who were taught using traditional meth- 
ods) of Master-degree students. Purposefully designed testing in History of Music covered different aspects of the students' professional competence: its cognitive component (key and specific knowledge of the history of domestic music art development, specific laws of art, understanding music genres, etc.), maturity of analytical and listening skills (the ability to recognize a music work by the tone, determine its genre, etc.), maturity of axiological skills. It should be noted that some tasks were designed in the form of a music quiz to check the music perception skills and knowledge of Ukrainian music works by ear.

The assessment was performed using 100-point scale according to the requirements set (table 1).

Maturity levels of Master-degree students' vocational competence

\begin{tabular}{|c|l|}
\hline Level & \multicolumn{1}{c|}{ Requirements } \\
\hline $\begin{array}{c}\text { High level } \\
90-100 \text { points })\end{array}$ & $\begin{array}{l}\text { A student has copious music vocabulary, profound knowledge of the Ukrainian folk art, } \\
\text { knows the specificity of sacred music, peculiarities of the development of leading genres } \\
\text { of Ukrainian music, starting from ancient times until today, knows Ukrainian composers } \\
\text { and their works, can recognize music styles, determine the names of music works, etc. }\end{array}$ \\
\hline $\begin{array}{c}\text { Average level (75- } \\
89 \text { points })\end{array}$ & $\begin{array}{l}\text { A student has quite profound knowledge of Ukrainian folklore, different genres of Ukrain- } \\
\text { ian composers' works, knows quite a lot of music terms, can use them in different occupa- } \\
\text { tion-related situations; sometimes manifests his/her analytical thinking skills, can recog- } \\
\text { nize composers and the genre almost without any mistakes, etc. }\end{array}$ \\
\hline $\begin{array}{c}\text { Low level (60-74 } \\
\text { points) }\end{array}$ & $\begin{array}{l}\text { A student is familiar with music terminology to a limited extent, makes mistakes when } \\
\text { using terms and concepts, can recognize the authors of the work heard but cannot recog- } \\
\text { nize its genre. }\end{array}$ \\
\hline $\begin{array}{c}\text { Unsatisfactory level } \\
(50-59 \text { points })\end{array}$ & $\begin{array}{l}\text { A student is hardly familiar with music terminology, cannot use it, has poor knowledge of } \\
\text { Ukrainian folklore and composers, makes lots of mistakes when trying to recognize both a } \\
\text { composer and genre of a music work by ear. }\end{array}$ \\
\hline
\end{tabular}

Table 2 demonstrates the indices of the final testing in each group.

Table 2.

Levels of Master-degree music students' professional competence maturity (EG and CG)

\begin{tabular}{|c|c|c|c|c|}
\hline \multirow{2}{*}{ Levels } & \multicolumn{2}{|c|}{ EG } & \multicolumn{2}{c|}{ CG } \\
\cline { 2 - 5 } & $\begin{array}{c}\text { Number of stu- } \\
\text { dents }\end{array}$ & $\%$ & Number of stu- & $\%$ \\
\hline High & 3 & 20 & 1 & 6,7 \\
\hline Average & 6 & 40 & 5 & 33,3 \\
\hline Low & 5 & 33,3 & 5 & 33,3 \\
\hline Unsatisfactory & 1 & 6,7 & 4 & 26,7 \\
\hline
\end{tabular}

The research outcomes are presented in the form of diagrams in fig. 4 and fig. 5 .

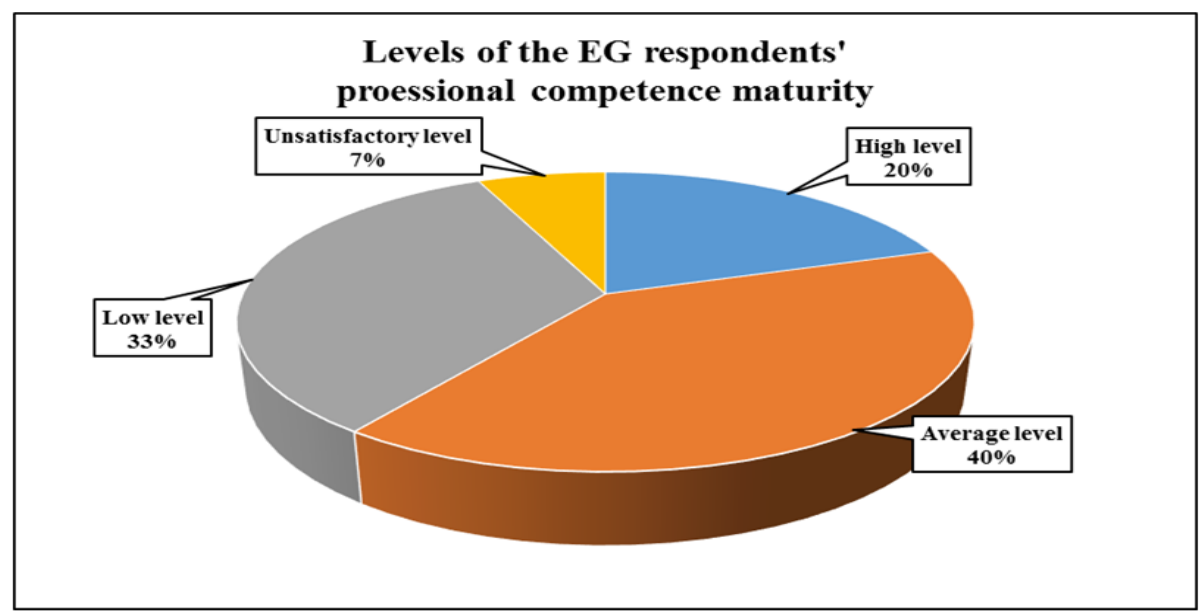

Fig. 4. The indices of Master-degree students' professional competence (EG) 


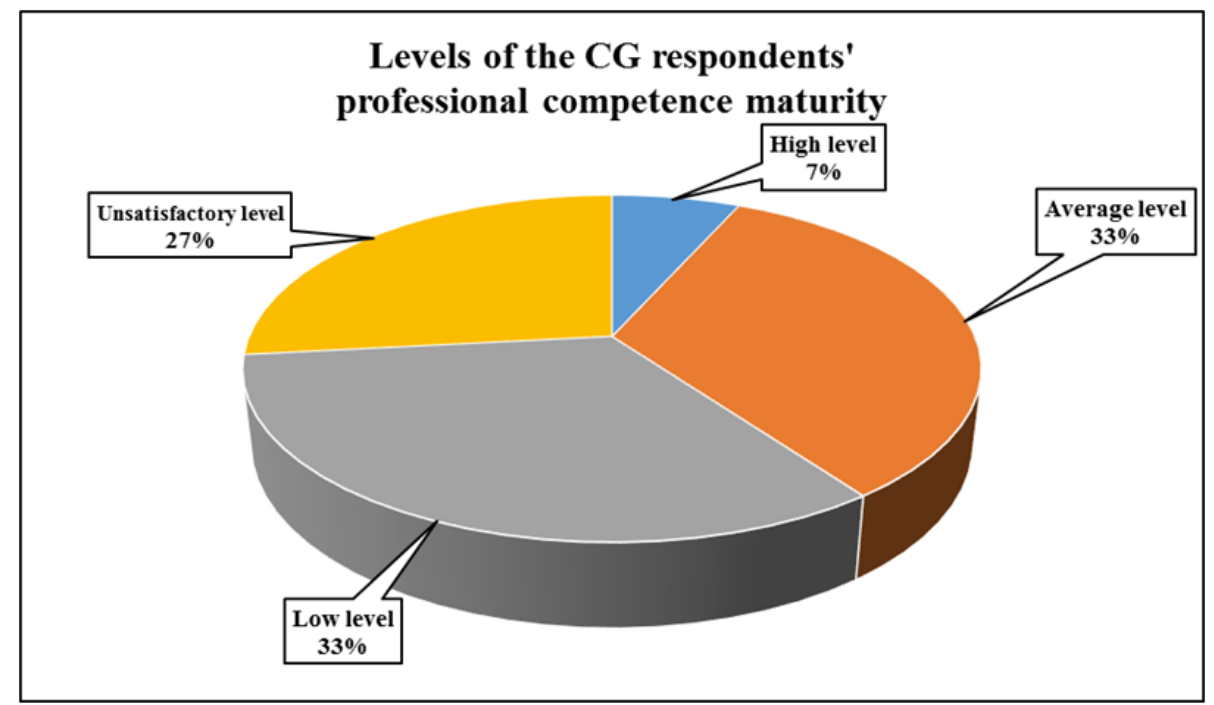

Fig. 5. The indices of Master-degree students' professional competence $(C G)$

The carried out assessment of the respondents' professional competence has proved the efficiency of using e-learning in terms of the online course "History of Music Art in Ukraine".

\section{Conclusions}

The specificity of using computer technologies in terms of implementing online courses in the training process of future Masters in the field of Music involves active application of multimedia technologies; specific kinds of knowledge and skills assessment (online quizzes, multimedia tests), as well as distinguishing specific methods, such as music works illustrations, historical and cultural context creation, etc.

The further research studies are planned to cover the issue of implementing new forms and methods of elearning: scribing as a modern form of educational material visualization, intellectual maps and graphic novels as

\section{REFERENCES}

1. Bykov, V. Yu., Kukharenko, V. M., Syrotenko, N. H., Rybalko, O. V., Bohachkov, Yu. M. (2008). Tekhnolohii rozrobky dystantsiinoho kursu: navchalnyi posibnyk [The technologies of designing the distance course]. Kyiv: Milenium [in Ukrainian].

2. Kukharenko, V. M. (2015). Systemnyi pidkhid do zmishanoho navchannia [System approach to blended learning]. Informatsiini tekhnolohii v osviti - Information Technologies in Education, 24, 53-67. DOI:10.14308/ite000568 [in Ukrainian].

3. Rosenberg M. (2007). Beyond E-Learning: New Approaches to Managing and Delivering Organiza-

\section{ЛIТЕРАТУРА}

1. Кухаренко В. М. Системний підхід до змішаного навчання / В. М. Кухаренко // Інформаційні технології в освіті. - 2015. - № 24. - C. 53-67. DOI:10.14308/ite000568. kinds of modern educational infographics, etc. Besides, we believe that it is reasonable to implement some social media into the process of teaching Music students (Facebook, Google+, Linkedin, etc.); as well as other multimedia resources (Youtube/Vimeo, Flickr/Picasa, Pinterest, Glogster, Animoto/goAnimate/Xtranorma, etc.), documents exchange services (Slideshare, Prezi, Dropbox, Google Drive, Webspiration, Ustream, etc.), real-time communication tools (Hangout, Skype, Viber, Dimdim, etc.), as well as team collaboration services (Wiki, Google Drive, Zoh, etc.).

Besides, we plan to apply e-learning techniques for teaching theoretical disciplines "Music Works Analysis", "Polyphony", "Music and Solmization Theory", as well as to combine them with traditional methods, using blended learning techniques.

tional Knowledge. ASTD International Conference. June 3. Atlanta [in English].

4. Simonson, M., Smaldino, S., Albright, M. \& Zvacek, S. (2003). Teaching and learning at a distance: foundations of distance education, (2nd Ed.). Upper Saddle River, NJ: Merrill Prentice Hall [in English].

5. Toru Iiyoshi \& M. S. Vijay Kumar (2009). Opening Up Education. The Collective Advancement of Education through Open Technology, Open Content, and Open Knowledge. London, The MIT Press [in English].

2. Технології розробки дистанційного курсу: навчальний посібник / [Биков В. Ю., Кухаренко В. М., Сиротенко Н. Г., Рибалко О. В., Богачков Ю. М.]; за ред. В. Ю. Бикова та В. М. Кухаренка. - К.: Міленіум, 2008. -324 c. 
3. Rosenberg M. Beyond E-Learning: New Approaches to Managing and Delivering Organizational Knowledge / M. Rosenberg // ASTD International Conference. - 2007. - June 3. - Atlanta.

4. Simonson M. Teaching and learning at a distance: foundations of distance education / M. Simonson,

S. Smaldino, M. Albright \& S. Zvacek. - 2nd ed. - Upper Saddle River, NJ: Merrill Prentice Hall. - 2003.

5. Toru Iiyoshi Opening Up Education. The Collective Advancement of Education through Open Technology, Open Content, and Open Knowledge / Iiyoshi Toru \& M. S. Vijay Kumar. - London, The MIT Press, 2009. $256 \mathrm{p}$.

Людмила Гаврилівна Гаврілова, доктор педагогічних наук, дочент, завідувач кафедри теорії і практики початкової освіти,

Надія Сергї̈вна Воронова, кандидат філософських наук, дочент кафедри культурології, естетики та історії, Донбаський державний педагогічний університет, вул. ген. Батюка, 19, м. Слов'янськ, Украӥна

\section{ВИКОРИСТАННЯ ЗАСОБІВ ДИСТАНЦИЙНОГО НАВЧАННЯ У ПРОФЕСІЙНІЙ ПІДГОТОВЦІ МАГІСТРІВ МУЗИЧНОГО МИСТЕЦТВА}

Актуальність проблеми обумовлюється інтенсивним упровадженням в освітні системи різних країн світу інформаційно-комунікаційних, зокрема комп’ютерних, технологій. Наразі створено міцне нормативно-правове, науково-теоретичне й методологічне підгрунтя впровадження ІКТ в освіту, проаналізовано й експериментально апробовано нові освітні форми: дистанційне навчання (distance education, e-learning), відкрита освіта (ореn еducation), змішане навчання (blended learning) тощо. Метою дослідження $є$ оприлюднення й аналіз авторського досвіду проектування й розроблення дистанційних курсів для системи професійної підготовки магістрів музичного мистецтва, а саме професійно зорієнтованого історико-теоретичного музикознавчого курсу «Історія музичного мистецтва України» та спецкурсу інформаційно-комунікаційного спрямування «Мультимедійні технології в мистецькій освіті». Курси створені для забезпечення високого рівня професійної підготовки майбутніх учителів музики, здобувачів ступеня вищої освіти «магістр». У статті також розглянуто питання специфіки розроблення й використання дистанційних курсів, які входять до сучасної музичної освіти відповідно до вимог інформаційно-комунікаційного педагогічного середовища. Специфічними особливостями використання комп’ютерних технологій у дистанційних курсах для майбутніх магістрів музичного мистецтва $\epsilon$ такі: широке застосування засобів мультимедіа до всіх видів навчальної діяльності та ресурсів дистанційного курсу; використання специфічних видів контролю музичних знань і умінь (онлайн-вікторини, мультимедійні тестові завдання); виокремлення специфічних методів дистанційного навчання, зокрема візуалізації музичних творів, створення історико-культурного контексту, залучення міжхудожніх асоціацій та ін. Згідно з результатами проведеного експериментального дослідження було підтверджено ефективність дистанційного навчання для розвитку професійної компетентності студентів магістратури напрямку «Музична освіта». Перспективи подальшого наукового пошуку полягають у залученні нових форм і методів дистанційного навчання: скрайбінгу як сучасної форми візуалізації навчального матеріалу, інтелектуальних мап та коміксів як різновидів сучасної навчальної інфографіки. Певні перспективи має залучення до дистанційного навчання майбутніх музикантів-педагогів можливостей соціальних медіа, зокрема педагогічного потенціалу електронних соціальних мереж, сервісів обміну мультимедійними даними, документами, сервісів комунікації в реальному часі, співробітництва та роботи в групі. Крім того, до професійної підготовки майбутніх магістрів музичного мистецтва доцільно залучати й дистанційні курси $з$ музично-теоретичних курсів «Аналізу музичних творів», «Поліфонії», «Теорії музики й сольфеджіо», поєднуючи традиційні форми з інноваційними методами дистанційного навчання музики.

Ключові слова: дистанційне навчання, дистанційний курс, історія музичного мистецтва України, мультимедійні технології в мистецькій освіті, майбутні магістри музичного мистецтва

Submitted on May, 31, 2017 